\title{
Trypsin-Immobilized Silica: A Novel Adsorbent for V(IV) and V(V) Removal from Water
}

\author{
Aslı Erdem Yayayürük ${ }^{1,2^{*}}$, Talal Shahwan ${ }^{3}$, Gülşah Şanlı-Mohamed ${ }^{1}$, Ahmet E. Eroğlu ${ }^{1}$
}

ABSTRACT: In the present study, trypsin-immobilized silica was employed for the removal of $\mathrm{V}(\mathrm{IV})$ and $\mathrm{V}(\mathrm{V})$ ions from water. The synthesized sorbent was first characterized and then investigated for the removal of $\mathrm{V}(\mathrm{IV})$ and $\mathrm{V}(\mathrm{V})$ under various experimental conditions. The adsorption performance of the sorbent was tested as a function of $\mathrm{pH}$, sorbent amount, initial vanadium concentration, contact time, and temperature. The sorption process was then investigated, both from a kinetic perspective and also in terms of isotherm models. The Langmuir adsorption isotherm was the best model to describe the sorption process. Sorption thermodynamics were spontaneous and exothermic. The proposed method was successfully applied to real samples for the removal of $\mathrm{V}(\mathrm{IV})$ and $\mathrm{V}(\mathrm{V})$ with sufficient accuracy and precision. Water Environ. Res., 90, 2056 (2018).

KEYWORDS: vanadium, removal, trypsin, silica, inductively coupled plasma mass spectrometry.

doi:10.2175/106143017X15131012188196

\section{Introduction}

Vanadium is widely distributed in the earth's crust and has been recognized as a potentially dangerous pollutant in the same class as mercury, lead, and arsenic (Imtiaz et al., 2015; Lazaridis et al., 2003; Padilla-Rodríguez et al., 2015). It exists in the environment both as tetravalent $[\mathrm{V}(\mathrm{IV})]$ and pentavalent $[\mathrm{V}(\mathrm{V})]$ forms, of which the pentavalent form is more toxic (Patel et al., 1990). $\mathrm{V}(\mathrm{V})$ is the predominant stable species of this element in oxidative conditions; however, in an anoxic medium, V(IV) occurs in significant amounts. Vanadium removal from water has become an important environmental concern in the last few decades as its compounds are of particular interest in many applications such as glass, textile, ceramic, photography,

\footnotetext{
${ }^{1}$ Department of Chemistry, İzmir Institute of Technology, Urla, 35430, Izmir, Turkey.

2 Department of Chemistry, Ege University, Bornova, 35100, İzmir, Turkey.

${ }^{3}$ Department of Chemistry, Birzeit University, Ramallah, West Bank, Palestine.

"Department of Chemistry, Ege University, Bornova, 35100, İzmir, Turkey; e-mail: aslierdem30@hotmail.com.
}

metallurgy, rubber, and plants producing industrial inorganic chemicals and pigments (Bhatnagar et al., 2008). In terms of environmental considerations, vanadium is greatly important, because it is mainly emitted into the environment from industrial sources, especially oil refineries and power plants using vanadium-rich fuel oil and coal. Also, phosphoric acid production using phosphorous ores results in the extraction of large amounts of vanadate ions from the ores, which make the acid unsuitable for use in food processing because of its toxicity (Lazaridis et al., 2003). Such sources can mobilize appreciable amounts of vanadium and increase the natural background level (Pyrzynska et al., 2004).

Excess amounts of vanadium in humans can cause anemia, coughing, emaciation, irritation of mucous membrane, gastrointestinal disturbances, and bronchopneumonia, as well as increasing the risk of lung cancer (Moskalyk and Alfantazi, 2003). Although vanadium acts as a growth-promoting factor in plants, a high concentration of vanadium reduces plant productivity. Vanadium is presently registered in the Contaminant Candidate List (CCL) and it will possibly be included as a regulated contaminant in the near future by the United States Environmental Protection Agency (U.S. EPA, 2009). Therefore, its removal from water is of significant importance from an environmental point of view. In recent years, several biological and chemical treatments have been applied to remove vanadium ions from water (Abbas and Conway, 2002; Chen and Owens, 2008; Guzman et al., 2002; Leiviska et al., 2015, 2017; Li et al., 2016; Naeem et al., 2007; Nukatsuka et al., 2002; Okamura et al., 2001; Roccaro and Vagliasindi, 2015; Vega et al., 2003; Xiong et al., 2010; Zhang et al., 2015) but there is still a strong need for studies in terms of water reclamation and remediation.

Recently, enzyme immobilization onto silica-based porous materials has gained the attraction of researchers because of their large surface area and tunable pore diameter, and easy recovery of the immobilized enzyme at the end of the reaction and thus its potential reuse (Salis et al., 2005). This present study has investigated the removal of vanadyl $[\mathrm{V}(\mathrm{IV})]$ and vanadate $[\mathrm{V}(\mathrm{V})]$ ions from water using a novel adsorbent: trypsinimmobilized silica. This study first focuses on the synthesis and characterization of trypsin-immobilized silica and then the use 
of the novel sorbent for the removal of $\mathrm{V}(\mathrm{IV})$ and $\mathrm{V}(\mathrm{V})$ ions under various experimental conditions. The effects of $\mathrm{pH}$, sorbent amount, contact time, and initial ion concentration are investigated to clarify sorption properties. The sorption thermodynamics and equilibrium isotherms for the removal of $\mathrm{V}(\mathrm{IV})$ and $\mathrm{V}(\mathrm{V})$ ions are also elucidated. Finally, the applicability of the sorbent to real sample analysis (ultrapure, tap, and bottled drinking water) is evaluated.

\section{Methodology}

Reagents and Apparatus. All reagents and chemicals were of analytical grade. Ultrapure water (18.2 M $\Omega$, Millipore, Billerica, MA, U.S.A.) was used throughout the study. Glassware and plasticware were cleaned by soaking in $10 \%(\mathrm{v} / \mathrm{v})$ nitric acid and were rinsed with distilled water before use. Standard V(IV) and V(V) stock solutions were prepared by dissolving appropriate amounts of vanadyl sulfate pentahydrate ( $\mathrm{VOSO}_{4} .5 \mathrm{H}_{2} \mathrm{O}$ in $0.5 \mathrm{~mol} / \mathrm{L} \mathrm{H}_{2} \mathrm{SO}_{4}$ ) and vanadium pentoxide $\left(\mathrm{V}_{2} \mathrm{O}_{5}\right.$ in $\left.1 \%(\mathrm{v} / \mathrm{v}) \mathrm{HNO}_{3}\right)$, respectively. Lower concentration standards were prepared daily from their stock standard solutions. 3-aminopropyl triethoxysilane (3-APTES), porous silica (particle diameter $0.2-0.5 \mathrm{~mm}$ ), and trypsin were obtained from Merck.

The inductively coupled plasma mass spectrometer (ICP-MS) used for vanadium determination $(m / z=51$, natural abundance of $99.75 \%$ ) was an Agilent 7500ce (Tokyo, Japan) type instrument equipped with a high solid nebulizer, a Peltier-cooled spray chamber $\left(2{ }^{\circ} \mathrm{C}\right)$, and an octopole collision/reaction cell with hydrogen gas pressurization (purity of $99.999 \%$ ). The ICPMS operating conditions were as follows: forward power of $1500 \mathrm{~W}$, plasma gas flow of $15.0 \mathrm{~L} / \mathrm{min}$, carrier gas flow of 1.1 $\mathrm{L} / \mathrm{min}$, collision gas flow of $3.5 \mathrm{~mL} / \mathrm{min}$; sample uptake time of $25 \mathrm{~s}$ and integration time of $100 \mathrm{~ms}$. In batch sorption studies, a GFL 1083 water bath shaker (Burgwedel, Germany) equipped with a microprocessor-controlled thermostat was used to provide efficient mixing. The $\mathrm{pH}$ measurements were performed using a Denver $\mathrm{pH} /$ ion meter (Colorado, U.S.A.) with a $\mathrm{pH} /$ ATC plastic-body electrode.

Synthesis of Trypsin-Immobilized Silica. Trypsin is an enzyme with a molecular mass of $23.400 \mathrm{Da}$ and belongs to the group of serine proteases, with an active site consisting of aspartic acid, histidine, and serine residues. The surface of trypsin possesses $\mathrm{S}-\mathrm{S}$, amine, and thiol groups. Surface activation by washing the silica surface with acetic acid is the first step in the synthesis of trypsin-immobilized silica.

Consequently, $1 \mathrm{~g}$ of dry silica gel was mixed with $15 \%$ (v/v) 3APTES in $20 \mathrm{~mL}$ acetone and incubated at $50{ }^{\circ} \mathrm{C}$ for $2 \mathrm{~h}$ with constant mixing. The treated silica gel was then washed with water, dried at $60.0{ }^{\circ} \mathrm{C}$ for $2.0 \mathrm{~h}$, and suspended in $0.05 \mathrm{M}$ phosphate buffer ( $\mathrm{pH} 7.0$ ). Glutaraldehyde, as the cross-linking agent, was added to the silica suspension, stirred at $20^{\circ} \mathrm{C}$ for $2 \mathrm{~h}$ and then filtered. The resulting activated silica gel was incubated overnight at $4.0{ }^{\circ} \mathrm{C}$ with $50.0 \mathrm{mg}$ trypsin in $10.0 \mathrm{~mL} 0.05 \mathrm{M}$ TRIS/HCl buffer ( $\mathrm{pH}$ 8.0) with $0.02 \mathrm{M} \mathrm{CaCl}_{2}$ (to reduce enzyme autodigestion). The carrier was then washed with TRIS buffer and vacuum filtered through a Buchner funnel. The reaction scheme is outlined in Figure 1.

Characterization. A number of characterization methods were employed to assess the attachment of the functional groups to the silica surface. Characterization of the proposed sorbent was performed using techniques namely, Brunauer-EmmettTeller (BET) surface area analysis, scanning electron microscopy (SEM), and thermal gravimetric analysis (TGA). Moreover, particle size distribution and zeta potential of the sorbent were also elucidated. The Bradford method was used in order to determine the protein content of the effluents after immobilization (Bradford, 1976). Blank, standards, and protein samples were prepared in the same manner and ultraviolet-visible spectrometry (at $595 \mathrm{~nm}$ ) was used in measurements. The enzyme activity was monitored by using p-toluene sulfonyl arginine methyl ester (TAME) as the substrate and the specific activity was expressed as unit of enzymatic activity per mg protein (Worthington, 1972).

Sorption/Desorption Studies. Separate standard solutions of $\mathrm{V}(\mathrm{IV})$ and $\mathrm{V}(\mathrm{V}),(1 \mathrm{mg} / \mathrm{L})$ were prepared at different $\mathrm{pH}$ values using various concentrations of $\mathrm{HNO}_{3}$ and $\mathrm{NH}_{3}$. From each of these solutions, $10 \mathrm{~mL}$ was taken and added into $10 \mathrm{mg}$ of the sorbent. The resulting mixture was shaken manually for 1 to $2 \mathrm{~min}$ and then for a further $30 \mathrm{~min}$ on a shaker at $25^{\circ} \mathrm{C}$. At the end of the shaking period, the mixture was filtered through blue-band filter paper and the filtrate was analyzed for its vanadium content by ICP-MS. The effects of $\mathrm{pH}$, sorbent amount, contact time, initial ion concentration, solution volume, temperature, and sorption behavior via steps of synthesis were investigated. The percentage of vanadium sorption was calculated using eq 1 , where $C_{i}$ is the initial and $C_{f}$ is the final concentration in the solution.

$$
\text { Sorption } \%=\frac{C_{i}-C_{f}}{C_{i}} \times 100
$$

After collection of $\mathrm{V}(\mathrm{IV})$ and $\mathrm{V}(\mathrm{V})$ ions on trypsin-immobilized silica, several eluents (EDTA, $\mathrm{HNO}_{3}, \mathrm{HCl}$, and thiourea) were tested for desorption of the analytes from the sorbent. For this purpose, $10 \mathrm{~mL}$ of $1 \mathrm{mg} / \mathrm{L} \mathrm{V}(\mathrm{IV})$ and $\mathrm{V}(\mathrm{V})$ was prepared and $10 \mathrm{mg}$ of the sorbents were added. After shaking for $30 \mathrm{~min}$, the mixtures were filtered and the sorbents were taken into the eluents $(10 \mathrm{~mL})$. The new mixture was shaken once again for 30 min. Finally, the resulting solutions were filtered and the filtrates were analyzed for their vanadium content by ICP-MS.

To evaluate the accuracy and applicability of the proposed method, sorption/desorption experiments were performed with ultrapure, $(18 \mu \mathrm{S} / \mathrm{cm}, \mathrm{pH} 6.2)$, tap $(905 \mu \mathrm{S} / \mathrm{cm}, \mathrm{pH} 7.3)$, and bottled drinking $(101 \mu \mathrm{S} / \mathrm{cm}, \mathrm{pH} 7.05)$ water samples. The water samples were filtered through a membrane filter (pore size 0.45 $\mu \mathrm{m})$ and analyzed as soon as possible after sampling. The water samples were spiked with various amounts of $\mathrm{V}(\mathrm{IV})$ and $\mathrm{V}(\mathrm{V})$, and the analysis was carried out under optimized conditions. Blank samples were also prepared in the same manner and analyzed by ICP-MS.

Sorption Isotherm Models. The equilibrium conditions of the sorption process were described using the sorption 


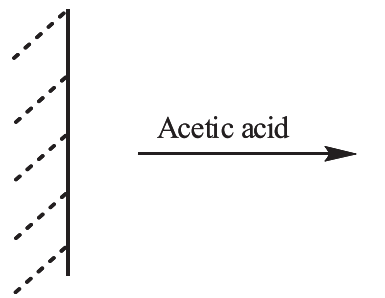

(A)

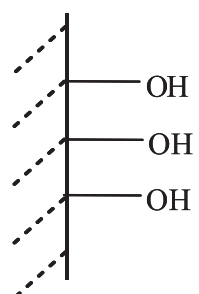

(B)
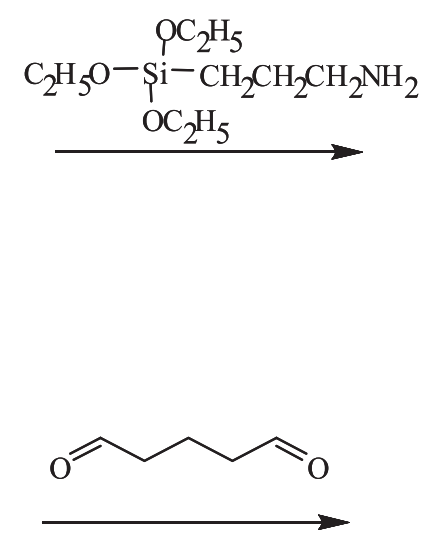

(C)

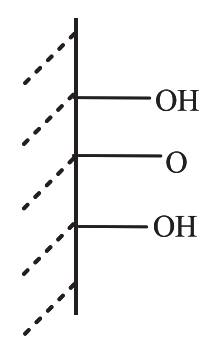

(D)

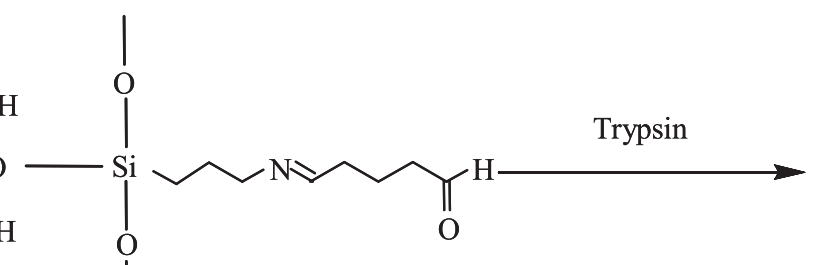

Trypsin

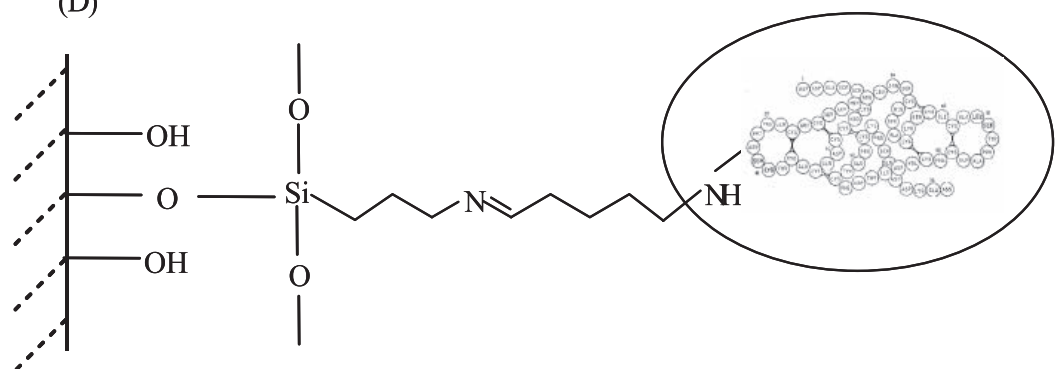

(E)

Figure 1-Trypsin immobilization to silica surface. (a) Silica surface, (b) activated silica, (c) 3-APTES-modified silica, (d) glutaraldehyde-treated silica, and (e) trypsin-immobilized silica.

isotherms. The relating studies were also performed through the batch process $(10 \mathrm{mg}$ trypsin-immobilized silica, $10 \mathrm{~mL}$ of solution volume, vanadium concentrations ranging from 100$1000 \mathrm{mg} / \mathrm{L}$, contact time of $60 \mathrm{~min}, \mathrm{pH} 4$ at $25^{\circ} \mathrm{C}$ ). Many theoretical and empirical models have been developed to represent the various types of adsorption isotherms. Langmuir, Freundlich, and Dubinin-Radushkevich are among the most frequently used isotherm models for this purpose.

The nonlinear form of Langmuir isotherm is given in eq 2:

$$
Q_{e}=Q_{\max } \frac{b C_{e}}{1+b C_{e}}
$$

where $Q_{\max }(\mathrm{mmol} / \mathrm{g})$ and $b(\mathrm{~L} / \mathrm{mmol})$ are Langmuir constants, $Q_{\max }$ is the amount of vanadate ion sorption corresponding to monolayer coverage, $b$ is the affinity of the species for the sorbent, $C_{e}(\mathrm{mmol} / \mathrm{L})$ is the amount of vanadate in liquid phase at equilibrium, and $Q_{e}$ is the amount of vanadate sorbed on the surface of the sorbent $(\mathrm{mmol} / \mathrm{g})$ at equilibrium. The values of the constants are evaluated from the linearized form of the equation, which is given in eq 3 :

$$
\frac{1}{Q_{e}}=\frac{1}{Q_{\max }}+\frac{1}{Q_{\max } b C_{e}}
$$

The intercept and the slope of the plot of $1 / Q_{e}$ versus $1 / C_{e}$ were used in the determination of $Q_{\max }$ and $b$ (Gueu at al. 2007; Limousin et al., 2007; Qi and Xu, 2004).

The Freundlich model is usually used to describe sorption over a wide range of concentrations on homogeneous and/or heterogeneous surfaces (Umpleby et al., 2001). The isotherm is not restricted to monolayer sorption and displays various nonlinear behaviors reflected in the value of its exponential parameter $(1 / n)$. The general nonlinear form of this isotherm is 
described by eq 4 :

$$
Q_{e}=K_{F} C_{e}^{1 / n}
$$

where $K_{F}(\mathrm{mg} / \mathrm{g})$ and $n$ are Freundlich constants that apply for a set of concentrations at a given temperature for a certain sorbent-sorbate system. These constants are determined from the linearized form of eq 5 given as follows:

$$
\log Q_{e}=\log K_{F}+\frac{1}{n} \log C_{e}
$$

The intercept and the slope of $\log Q_{e}$ versus $\log C_{e}$ plot give $K_{F}$ and $1 / n$, respectively.

The Dubinin-Radushkevich isotherm model assumes that the ionic species preferentially bind to the most energetically favorable sorbent sites associated with the multilayer adsorption of ions (Taqvi et al., 2007). The Dubinin-Radushkevich isotherm is generally described by eqs 6 and 7 (Kavitha and Namasivayam, 2007):

$$
Q_{e}=q_{s} \exp \left(-B \varepsilon^{2}\right)
$$

where:

$$
\varepsilon=R T \ln \left(1+\frac{1}{C_{e}}\right)
$$

The Dubinin-Radushkevich parameter, $B\left(\mathrm{~mol}^{2} / \mathrm{kJ}\right)$, gives information about the mean free-energy of sorption per molecule of sorbate which is required to transfer it to the surface of the solid from infinity in the solution; $q_{s}(\mathrm{mg} / \mathrm{g})$ corresponds to the sorption monolayer capacity (Yurdakoç et al., 2005). The mean free-energy of sorption can be calculated from the Dubinin-Radushkevich parameter $B$ by eq 8 :

$$
E=(2 B)^{-\frac{1}{2}}
$$

The constants $q_{s}$ and $B$ are calculated from the intercepts and the slope of the experimental plot, $\ln Q_{e}$ versus $\varepsilon^{2}$.

Thermodynamic Parameters. The effect of reaction temperature on the sorption of $\mathrm{V}(\mathrm{IV})$ or $\mathrm{V}(\mathrm{V})$ was studied at 25 and $60{ }^{\circ} \mathrm{C}$ while keeping the other parameters constant $(10$ $\mathrm{mL}$ of $1 \mathrm{mg} / \mathrm{L} \mathrm{V}(\mathrm{IV})$ or $\mathrm{V}(\mathrm{V})$ solutions, $10 \mathrm{mg}$ sorbent, $\mathrm{pH}$ of 4, $n=3)$. The corresponding standard Gibbs free-energy change, $\Delta G^{\circ}$, standard enthalpy change, $\Delta H^{\circ}$, and standard entropy change, $\Delta S^{\circ}$ were calculated utilizing the well-known eqs 9,10 , and 11 (Atkins, 2006).

$$
\begin{aligned}
\Delta G^{o} & =-R T \ln R_{d} \\
\Delta H^{o} & =R \ln \frac{R_{d}\left(T_{2}\right)}{R_{d}\left(T_{1}\right)}\left(\frac{1}{T_{1}}-\frac{1}{T_{2}}\right)^{-1} \\
\Delta S^{o} & =\frac{\Delta H^{0}-\Delta G^{o}}{T}
\end{aligned}
$$

\section{Results and Discussion}

Characterization of the Sorbent. The surface morphologies of unmodified and trypsin-immobilized silica were exam- ined at different surface locations using SEM. Visual inspection of the images (not shown) indicated an increase in surface roughness upon functionalization of the silica. This could be reflecting a strong interaction between the silica surface and the functional groups. In addition to SEM, elemental analysis was performed to reveal the percentages of carbon, hydrogen, nitrogen and silica in the synthesized sorbent. The appearance of nitrogen $(2.39 \%)$ on the surface and an increase in the percentages of carbon $(2.39 \%)$ and hydrogen $(2.39 \%)$ indicated the immobilization of trypsin to the silica surface. Thermal gravimetric analysis results indicated a 3 to $4 \%$ weight loss at $\sim 110{ }^{\circ} \mathrm{C}$ which could be attributed to the removal of adsorbed water. After $300{ }^{\circ} \mathrm{C}$, the weight decreased gradually (crosslinking with glutaraldehyde), where a weight loss of 15 to $18 \%$ was observed. Additionally, a weight loss of 20 to $25 \%$ was recorded when trypsin was immobilized on the sorbent, which could be an indication of surface modification. Thus, by considering the TGA results, it can be concluded that additional weight loss in the functionalized sorbent can also give information about the presence of functional groups on the silica surface.

Nitrogen sorption isotherm data was used to determine the specific surface areas of unmodified and trypsin-immobilized silica to express the concentration of reactive surface species. The decrease in pore volume from 0.101 to $0.053 \mathrm{~cm}^{3} / \mathrm{g}$ was likely to be an indication of the organic groups having been successfully introduced into the inner channels. In line with this, the decrease in specific surface area by nitrogen adsorption indicated coverage of the silica surface with the functional groups. It has been reported that nitrogen molecules were adsorbed preferentially to silanols and a weak adsorption was observed on organic surfaces compared with bare silica surfaces (Takei et al., 2000).

The zeta potential measurements were carried out as a function of $\mathrm{pH}$ and the zero point of charge (ZPC) of the unmodified silica and trypsin-immobilized silica was determined to be 2.5 and 9.0, respectively. The ZPC values indicated that the electrostatic nature of the two sorbents was significantly different. The particle size measurements showed that as the surface modification was performed smaller silica particles were obtained. This was probably a result of mechanical abrasion caused by stirring during the synthesis process. In addition, the particle size distribution of the novel sorbent also indicated a monodispersed distribution of particles.

Infrared spectra were used to verify the immobilization procedure (Figure not shown). The characteristic vibration bands at around 1101,800 , and $490 \mathrm{~cm}^{-1}$ correspond to the stretching, bending, and out-of-plane deformation vibrations of Si-O-Si bonds, respectively. The broad shoulder at $1300 \mathrm{~cm}^{-1}$ can be attributed to a $\mathrm{Si}-\mathrm{C}$ vibration. The small peaks observed in the spectral range of 1450 to $1600 \mathrm{~cm}^{-1}$ might be attributed to the $\mathrm{C}-\mathrm{H}$ asymmetric and symmetric stretching vibrations, $\mathrm{N}-\mathrm{H}$ deformation peak, and the $\mathrm{CH}_{2}$ and $\mathrm{CH}_{3}$ groups of the amino propyl. A very broad absorption band centered at $3450 \mathrm{~cm}^{-1}$ was assigned to hydrogen-bound surface $\mathrm{Si}-\mathrm{OH}$ groups as well as $\mathrm{NH}_{2}$ (Stuart, 2004) 


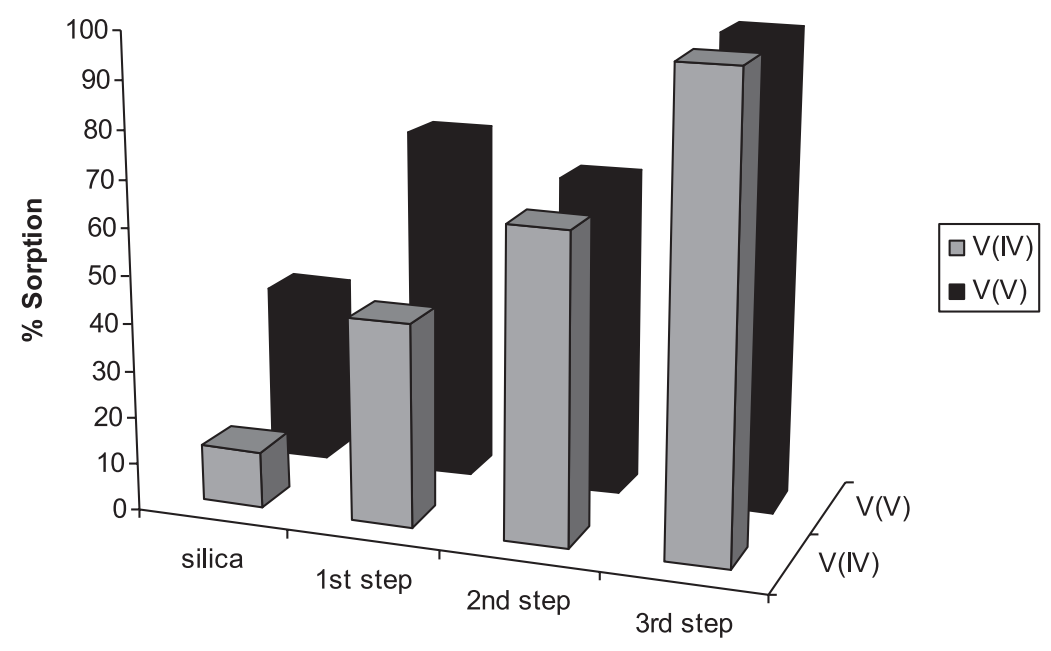

Figure 2-Sorption of V(IV) or V(V) towards trypsin-immobilized silica through steps of synthesis (1 $\mathrm{mg} / \mathrm{L} \mathrm{V(IV)}$ or $\mathrm{V}(\mathrm{V}), 10 \mathrm{mg}$ sorbent, $\mathrm{pH} \mathrm{4}$, and $30 \mathrm{~min}$ contact time at $\left.25{ }^{\circ} \mathrm{C}\right)$.

As explained in the Methodology section, the Bradford method was applied to determine the amount of protein bound to silica gel. Moreover, to check the effect of the amount of immobilized trypsin, two different trypsin concentrations (5-10 $\mathrm{mg}$ ) were tested. Almost a quantitative (92-96\%) immobilization of protein to silica was achieved. Therefore, it was concluded that increasing the initial amount of the trypsin from 5 to $10 \mathrm{mg}$ did not have a significant effect on the immobilization percent. Moreover, as activity retention on the support is one of the most important aspects in the enzyme immobilization process, any chemical modification or physical adsorption in the procedure of immobilization will affect their activity to some extent. The results obtained from activity experiments demonstrated that quantification of protease inhibitory activity via this method is feasible.

Sorption by the Intermediate Products During the Synthesis and Final Sorbent. Trypsin-immobilized silica was synthesized in four steps. The first step was to wash the silica with $\mathrm{H}_{2} \mathrm{O}_{2}$ or $\mathrm{CH}_{3} \mathrm{COOH}$ (or to use it as is). The second step was modification of the silica surface with 3-APTES. Next, the sorbent was cross-linked using glutaraldehyde and, finally. the synthesis was completed with the immobilization of trypsin.

After each step, an appropriate amount of the present product was taken and its sorption behavior was tested towards V(IV) and $(\mathrm{V})$ under the similar conditions. As can be seen from Figure 2 , the sorption percentage of the sorbent increased gradually as the synthesis proceeded. This indicates the applicability of trypsin-immobilized silica for vanadium sorption as well as the intermediate products in the overall synthesis. As can be seen from the figure, the sorption percentage decreased in the second step (glutaraldehyde addition after $\mathrm{NH}_{2}$ modification to the silica surface). The reason for this was the probably the steric effect of the surface, which prevented the approach of the vanadyl or vanadate species. In addition, although the first step $\left(\mathrm{NH}_{2}\right.$ attachment to the silica surface) was sufficient for the speciation of $\mathrm{V}(\mathrm{IV})$ and $\mathrm{V}(\mathrm{V})$, if the removal of total vanadium was required, trypsin immobilization became necessary.
Effect of $\mathrm{pH}$. Solution $\mathrm{pH}$ is one of the most important parameters that affect sorption as it not only affects the chemistry of the binding site of the sorbent, but also the speciation of the analytes strongly depends on the $\mathrm{pH}$ of the solution. Therefore, the ability of the trypsin-immobilized silica to retain vanadium from aqueous solution was investigated as a function of $\mathrm{pH}$. In addition to the individual sorption of the $\mathrm{V}(\mathrm{IV})$ and $\mathrm{V}(\mathrm{V})$ species examined, sorption was also investigated for the solution that contained both of the species together. As can be seen from Figure 3, the sorption percentage of the sorbents was almost constant in the $\mathrm{pH}$ range from 4 to 8 . Under acidic conditions $(\mathrm{pH} \leq 4)$, the adsorbent showed poor adsorption capacity for both of the species which was probably a result of the excess of $\mathrm{H}^{+}$ions competing with $\mathrm{V}(\mathrm{IV})$ and $\mathrm{V}(\mathrm{V})$. The adsorbent had a zero point of charge 9 , and it can be assumed that the adsorbent was negatively charged above this value. By considering the speciation graphs, $\mathrm{V}(\mathrm{V})$ was probably retained as $\mathrm{H}_{2} \mathrm{VO}_{4}^{+}$as the predominant species within the $\mathrm{pH}$ values 4 to 8 . The same trend for the sorption of $\mathrm{V}(\mathrm{IV})$ was also observed. In this case, $\mathrm{V}(\mathrm{IV})$ was possibly oxidized to $\mathrm{V}(\mathrm{V})$ by atmospheric oxygen, so percent sorption decreased (Filik et al., 2004). As a result, the effect of $\mathrm{pH}$ on the vanadium adsorption can be best explained on the basis of attractive forces between the positively-charged surface of trypsin-immobilized silica and negatively-charged $\mathrm{V}(\mathrm{IV})$ and $\mathrm{V}(\mathrm{V})$ species below $\mathrm{pH} 8$.

The decrease in sorption of $\mathrm{V}(\mathrm{IV})$ and $\mathrm{V}(\mathrm{V})$ species above $\mathrm{pH}$ 8 could be assigned to the electrostatic repulsion between the negatively-charged surface of the adsorbent and vanadium anions because the chemical form of the vanadium species $\left(\mathrm{VO}^{2+}\right.$ and $\mathrm{VO}_{2}^{+}$) changes to the anion $\mathrm{HVO}_{4}^{2-}$. Moreover, Fourier transform infrared (FTIR) was used to verify the sorption mechanism and no significant differences were observed in the FTIR spectra, once the vanadium was adsorbed for $\mathrm{V}(\mathrm{IV})$ and $\mathrm{V}(\mathrm{V})$; the bands corresponding to the different functional groups were similar to trypsin-immobilized silica bands. These results suggest no chelation effect occurs as a consequence of the adsorption process, which may be attributed 


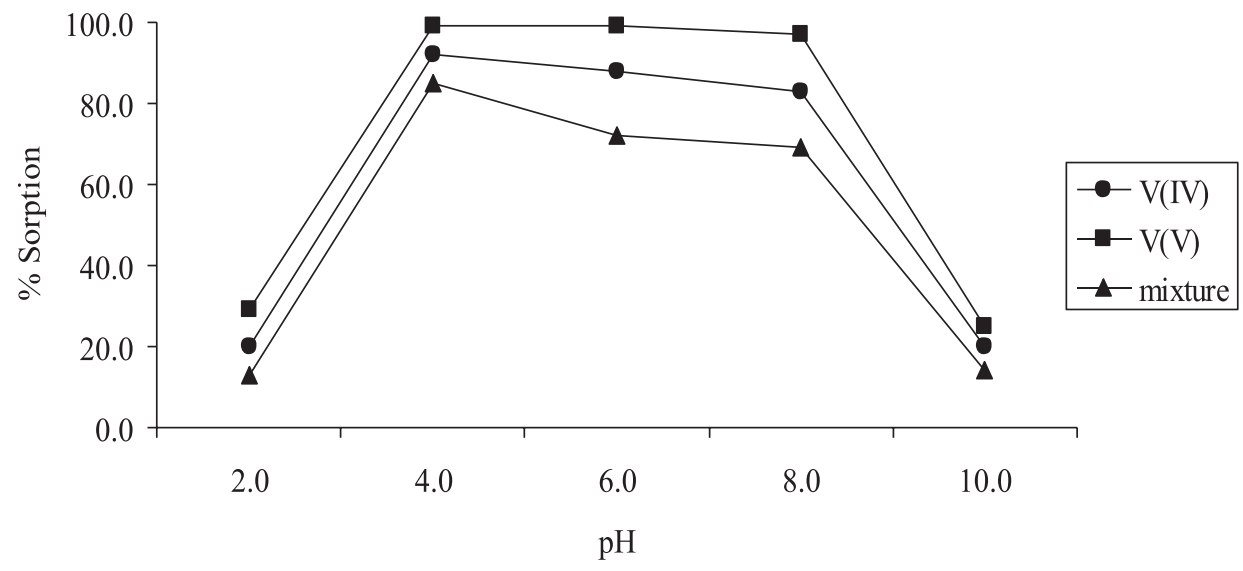

Figure 3-Effect of $\mathrm{pH}$ on the sorption of $\mathrm{V}(\mathrm{IV})$ and/or $\mathrm{V}(\mathrm{V})$ towards trypsin-immobilized silica (1 $\mathrm{mg} / \mathrm{L} \mathrm{V(V)}$ or $\mathrm{V}$ (IV) solution, $10 \mathrm{~mL}$ sample volume, $30 \mathrm{~min}$ contact time, $10 \mathrm{mg}$ sorbent at $25{ }^{\circ} \mathrm{C}$ ).

to an electrostatic attraction between the trypsin-immobilized silica and $\mathrm{V}(\mathrm{IV})$ and $\mathrm{V}(\mathrm{V})$ as the dominant mechanism. This evaluation is in accordance with similar works (Padilla-

Rodríguez et al., 2015).

The vanadium oxyanions species will oxidize in water rapidly from oxidation state (III) and (IV) to state (V); therefore, every vanadium species behaves as $\mathrm{V}(\mathrm{V})$ at high $\mathrm{pH}$ values (PadillaRodríguez et al., 2015). An additional experiment was performed to determine $\mathrm{V}(\mathrm{IV})$ and $\mathrm{V}(\mathrm{V})$ species. The samples were divided into two parts: in the first part of the study, total vanadium determination was performed for the determination of total vanadium concentration. For this purpose, $10 \%$ aqueous ascorbic acid was added and the $\mathrm{pH}$ of the solutions was adjusted to 4 with dilute ammonia. In the second part, sample solutions' $\mathrm{pH}$ was adjusted to 4 with dilute ammonia and no sample pretreatment was applied. As can be seen from Table 1, the two species of vanadium $[\mathrm{V}(\mathrm{IV})$ and $\mathrm{V}(\mathrm{V})]$ were completely separated and recovered quantitatively with a simple prereduction step before analysis.

In the case of sorption study with both of the vanadium together, it is clearly seen that the percent sorption decreased when compared with the individual sorption of $\mathrm{V}(\mathrm{IV})$ or $\mathrm{V}(\mathrm{V})$ species. The affinity of the trypsin-immobilized silica towards the different species of vanadium follows the trend: $V(V)>$ $\mathrm{V}(\mathrm{IV})>[\mathrm{V}(\mathrm{V})+\mathrm{V}(\mathrm{IV})]$ (Figure 3$)$. The greater selectivity of the trypsin-immobilized silica for $\mathrm{V}(\mathrm{V})$ over its counterpart $\mathrm{V}(\mathrm{IV})$ may be a result of its greater ionic potential and $\mathrm{pH}$ of hydrolysis. Typically, the adsorbent preferentially adsorbs ions in the order: pentavalent $>$ tetravalent $>$ trivalent $>$ divalent $>$ monovalent (Jansson-Charrier et al., 1996). On account of this, $\mathrm{V}(\mathrm{V})$ was taken preferentially. Similarly, the decrease in vanadium adsorption from its mixture was most probably the result of competitive adsorption of $\mathrm{V}(\mathrm{V})$ and $\mathrm{V}(\mathrm{IV})$ for the same surface sites. As a result of $\mathrm{pH}$ studies, to be on the safe side, a $\mathrm{pH}$ of 4 was used in all subsequent experiments for the quantitative sorption of vanadium species.

Effect of Sorbent Amount. The sorbent amount is also an important parameter in obtaining the quantitative uptake of metal ions. The effect of the amount of trypsin-immobilized silica on the sorption of $\mathrm{V}(\mathrm{IV})$ and $\mathrm{V}(\mathrm{V})$ was studied at $\mathrm{pH} 4$ with different sorbent doses varying from 5 to $200 \mathrm{mg}$ at a fixed ion concentration of $1 \mathrm{mg} / \mathrm{L}$. Based on the results obtained, it can be concluded that even with a very small amount of sorbent ( $5 \mathrm{mg}$ ), a quantitative sorption of vanadium species (>95\%) onto the sorbent was obtained which was probably a result of the high number of binding sites available for adsorbentadsorbate interaction. As no further increase in sorption after a certain amount of sorbent was observed, to be on the safe side, a sorbent amount of $10 \mathrm{mg}$ (sorbent amount/solution volume ratio of $1 \mathrm{mg} / \mathrm{mL}$ ) was used in subsequent studies for quantitative sorption of the target ions.

Effect of Contact Time. The sorption kinetics that describe the solute uptake rate governing the contact time of the sorption reaction is one of the important characteristics that define sorption efficiency. When sorption data for the uptake of $1 \mathrm{mg} / \mathrm{L}$ $\mathrm{V}(\mathrm{IV})$ and $\mathrm{V}(\mathrm{V})(\mathrm{pH} 4,10 \mathrm{mg}$ sorbent) at contact times of 1 to 90 min were examined, it was evaluated that vanadium sorption is not much dependent on time as a very rapid uptake of $\mathrm{V}(\mathrm{IV})$ and $\mathrm{V}(\mathrm{V})$ occurred, even in $1 \mathrm{~min}$. The initial sorption rate was very fast, probably because of the greater number of sorbent sites available for the sorption of vanadium ions This is one of the important advantages of the proposed sorbent as an adsorbent with faster uptake is better for the removal of heavy metals. As a

Table 1-Effect of sample pretreatment for the sorption of $\mathrm{V}(\mathrm{IV})$ and $\mathrm{V}(\mathrm{V})$ by trypsinimmobilized silica (1 mg/L V(IV) or V(V), $100 \mathrm{mg}$ sorbent, sorption time of $30 \mathrm{~min}$, $\mathrm{pH}$ 4).

\begin{tabular}{cccc}
\hline \multicolumn{2}{c}{ Added } & & \\
\hline V(IV) & $\mathbf{V}(\mathbf{V})$ & Sample Pretreatment & \% Recovery \\
\hline 1 & - & no & 99 \\
1 & - & yes & 104 \\
- & 1 & no & 98 \\
- & 1 & yes & 102 \\
1 & 1 & no & 98 \\
1 & 1 & yes & 103 \\
\hline
\end{tabular}


Table 2-Thermodynamic parameters for the sorption of $V(I V)$ and $V(V)$ by trypsinimmobilized silica (1 mg/L V(IV) or V(V), $100 \mathrm{mg}$ sorbent, sorption time of $30 \mathrm{~min}$, $\mathrm{pH}$ 4).

\begin{tabular}{|c|c|c|c|c|c|}
\hline & $\Delta \mathbf{G}^{\circ}($ & (mol) & & $\Delta \mathbf{S}^{\circ}($ & nolK) \\
\hline & $298 K$ & $\overline{333 \mathrm{~K}}$ & $\Delta H^{\circ}(\mathrm{kJ} / \mathrm{mol})$ & $298 \mathrm{~K}$ & $333 \mathrm{~K}$ \\
\hline $\mathrm{V}(\mathrm{IV})$ & -13.8 & -7.9 & -64.4 & -169 & -169 \\
\hline $\mathrm{V}(\mathrm{V})$ & -12.4 & -6.9 & -66.2 & -180 & -178 \\
\hline
\end{tabular}

result, to guarantee quantitative sorption, $30 \mathrm{~min}$ contact time was used in further studies.

Effect of Initial Concentration. The initial concentration serves as an important driving force for overcoming mass transfer resistance of metal ions between the aqueous and solid phases. To evaluate the effect of initial metal ion concentration on sorption behavior, solutions of $\mathrm{V}(\mathrm{IV})$ and $\mathrm{V}(\mathrm{V})$ were prepared with initial ion concentrations ranging from 0.01 to $1000.0 \mathrm{mg} / \mathrm{L}$ ( $\mathrm{pH}$ of $4.0,10.0 \mathrm{mg}$ sorbent). It was observed that the sorption percentage was higher for lower initial vanadium concentrations and decreased with increasing vanadium concentrations. As a sorbent has a limited number of active sites which become saturated at a certain concentration, the sorption capacity of the trypsin-immobilized silica was exceeded, leading to a decrease in sorption percentage at higher vanadium concentrations.

Effect of Sorption Temperature. Variation in temperature also affects the sorption of trace metal ions onto solid surfaces. The sorption of $\mathrm{V}(\mathrm{IV})$ and $\mathrm{V}(\mathrm{V})$ ions onto trypsin-immobilized silica was undertaken for temperatures 25 and $60{ }^{\circ} \mathrm{C}$ under optimized conditions, and a decrease in sorption percent with an increase in temperature was examined (Table 2). This observation associated with a decrease in entropy indicated that the spontaneous sorption was enthalpy-driven. The negative $\Delta \mathrm{G}^{\circ}$ values showed that the adsorption of vanadium species onto trypsin-immobilized silica was feasible and spontaneous. The negative $\Delta \mathrm{H}^{\circ}$ value illustrated the exothermic nature of the adsorption. The negative $\Delta S^{\circ}$ values revealed that the orderliness of the adsorbed system was higher than the solution phase before adsorption.

Effect of Sample Volume. In order to explore the possibility of concentrating low concentration of analytes from large volumes, the effect of sample volume on the retention of $\mathrm{V}(\mathrm{IV})$ and $\mathrm{V}(\mathrm{V})$ was also investigated. Two different routes were followed to understand the effect of sample volume. In the first route, 10, 25, 50, 100, 250, 500 and $1000 \mathrm{~mL}$ sample volumes at constant absolute amounts of $\mathrm{V}(\mathrm{IV})$ and $\mathrm{V}(\mathrm{V})(10 \mu \mathrm{g})$ were prepared. All the other parameters were kept constant at their respective optima. Quantitative recoveries (93-99\%) were obtained even with a sample volume of $500 \mathrm{~mL}$. This provides the use of the proposed methodology with relatively large sample volumes. On the other hand, almost $75 \%$ percent sorption was obtained both for $\mathrm{V}(\mathrm{IV})$ and $\mathrm{V}(\mathrm{V})$ for $1000 \mathrm{~mL}$ of sample volume. In the second route, sample volumes $(10,25,50$, $100,250,500$ and $1000 \mathrm{~mL}$ ) were changed while keeping the
$\mathrm{V}(\mathrm{IV})$ and $\mathrm{V}(\mathrm{V})$ concentration constant (absolute amount changed depending on the solution volume) at $1 \mathrm{mg} / \mathrm{L}$. As in the previous route, acceptable recoveries $(>90 \%)$ were obtained up to $1000 \mathrm{~mL}$ of sample volume. As a result, in both of the cases, above $500 \mathrm{~mL}$ the recoveries of the analytes decreased slightly, indicating the potential for use of the sorbent in water treatment and promoting an evaluation of a scale-up procedure.

Desorption from the Sorbent. Among the various concentrations of EDTA, $\mathrm{HNO}_{3}, \mathrm{HCl}$, and thiourea used for the desorption of $\mathrm{V}(\mathrm{IV})$ and $\mathrm{V}(\mathrm{V})$ from trypsin-immobilized silica, only $0.5 \mathrm{~mol} / \mathrm{L}$ thiourea (in $0.2 \mathrm{~mol} / \mathrm{L} \mathrm{HCl}$ ) gave efficient desorption $(93 \pm 3 \%)$ and $(89 \pm 5 \%)$ whereas the desorption percentage for the others ranged between 10 and $60 \%$.

Therefore, it was decided that $0.5 \mathrm{~mol} / \mathrm{L}$ thiourea (in $0.2 \mathrm{~mol} / \mathrm{L}$ $\mathrm{HCl}$ ) would be used as the eluent in further studies.

Sorption Isotherm Models. The sorption data at $25{ }^{\circ} \mathrm{C}$ were subjected to different sorption isotherms namely,

Langmuir, Freundlich, and Dubinin-Radushkevich to assess the sorption capacity of $\mathrm{V}(\mathrm{IV})$ and $\mathrm{V}(\mathrm{V})$ ions (Figure 4). It was evaluated that the Langmuir isotherm appeared to be linear for $\mathrm{V}(\mathrm{IV})$ and $\mathrm{V}(\mathrm{V})$ with a high correlation coefficient of 0.9317 and 0.9876 , respectively (Table 3 ). Moreover, the maximum sorption capacity values obtained from the Langmuir equation (19.4 and $72.4 \mathrm{mg} / \mathrm{g}$ for $\mathrm{V}(\mathrm{IV})$ and $\mathrm{V}(\mathrm{V})$, respectively) were in accordance with the experimental values obtained from eq 1 . These evaluations certified that the Langmuir isotherm well describes the sorption process, indicating monolayer coverage of the sorbent surface by the vanadium species. Moreover, the essential characteristics of the Langmuir isotherm can be expressed by a dimensionless constant separation factor, $R_{\mathrm{L}}$, which is given by eq 12 (Babu and Gupta, 2008; Hall et al., 1966).

$$
R_{L}=\frac{1}{1+K_{L} C_{i}}
$$

where $K_{\mathrm{L}}$ is the Langmuir constant and $C_{\mathrm{i}}$ is the initial concentration of the metal ion in solution. The separation factor, $R_{\mathrm{L}}$, represent the shape of the isotherm and the nature of the adsorption process. If $0<R_{\mathrm{L}}<1$, the sorption is favorable (Hall et al., 1966). The calculated values of $R_{\mathrm{L}}$ were found to be in the range of 0 to 1 at all initial metal concentrations of $\mathrm{V}(\mathrm{IV})$ and $\mathrm{V}(\mathrm{V})$. Therefore, the results indicate that the adsorption process was extremely favorable. In addition, an evaluation has been done to compare the sorption capacity of vanadium within the literature (Anirudhan and Radhakrishnan, 2010; Mthombeni et al., 2015; PadillaRodríguez et al., 2015; Parijaee et al., 2014; Sirviö et al., 2016; Yayayürük and Yayayürük, 2017) and vanadium uptake by trypsin-immobilized silica was found to be competitive in many cases which indicates the promising performance of the sorbent in vanadium removal studies.

Application to Real Samples. The applicability of the method to real samples was performed with standard additions for different matrices such as ultrapure, tap, and drinking water samples using the optimum conditions $(\mathrm{pH} \mathrm{4,10} \mathrm{mg} \mathrm{sorbent,}$ and contact time of $30 \mathrm{~min}$ at $25^{\circ} \mathrm{C}$ ). As can be seen from Table 

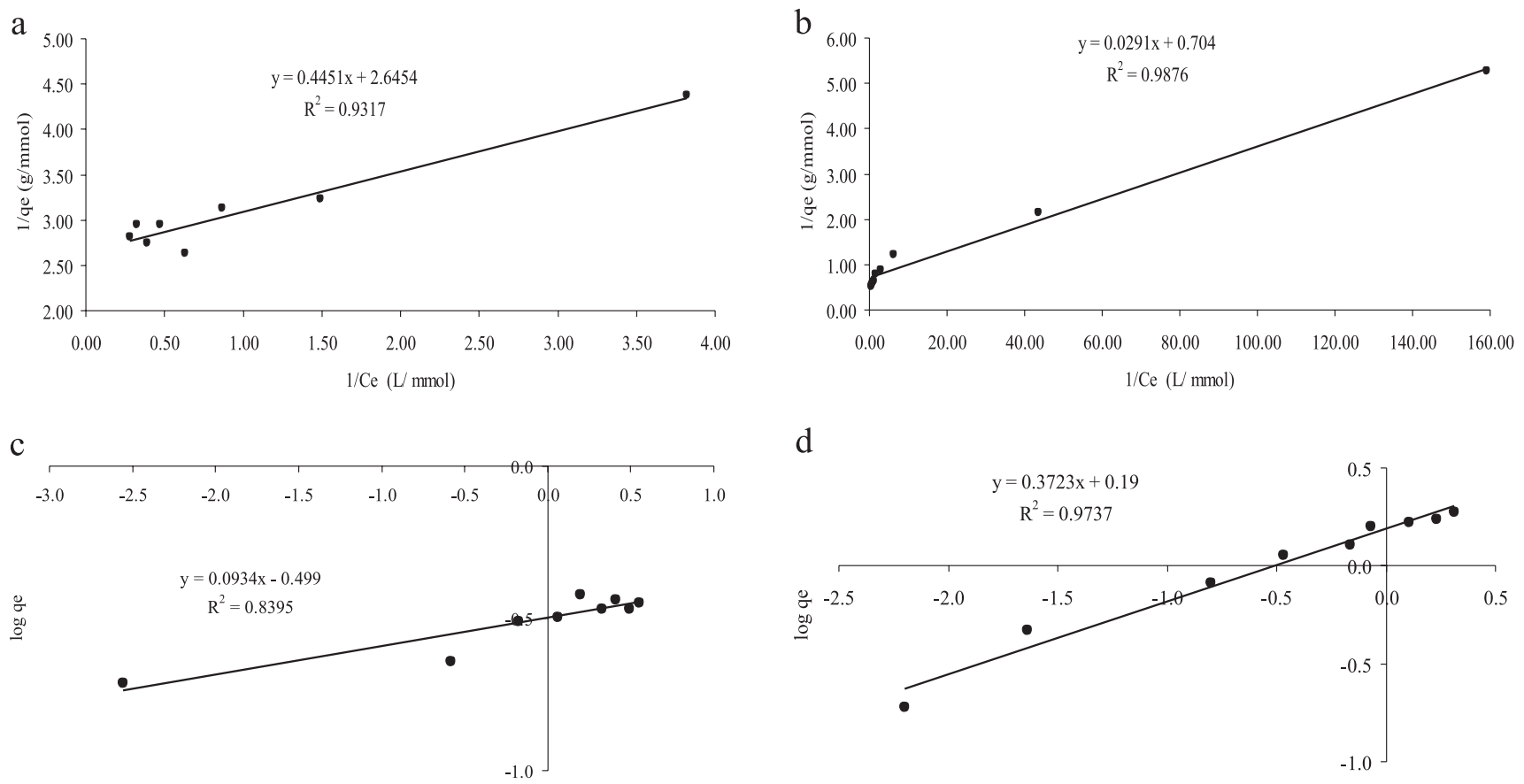

$\log \mathrm{Ce}$

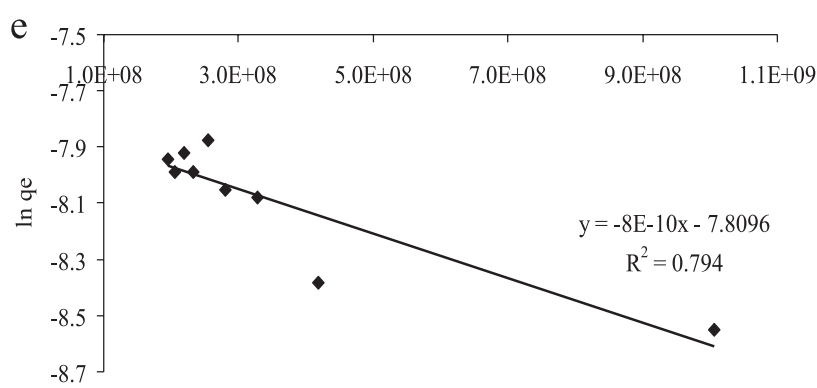

E2

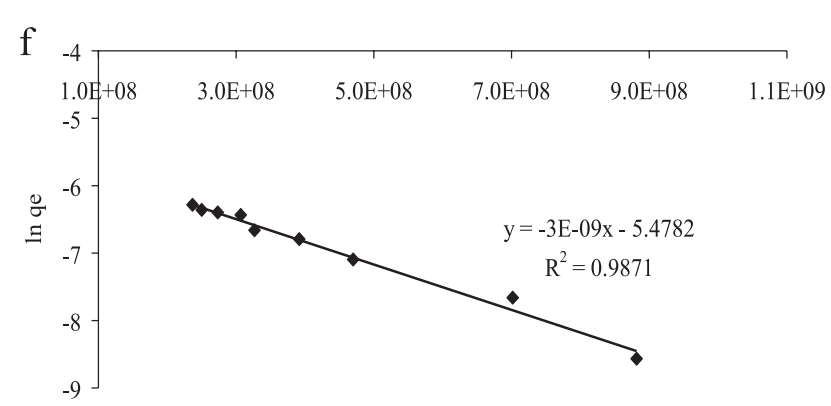

E2

Figure 4-Linear fits of Langmuir (a) V(IV), (b) V(V); Freundlich (c) V(IV), (d) V(V); and Dubinin-Radushkevich (e) $V(I V),(f) ~ V(V)$ isotherm models for vanadium sorption by trypsin-immobilized silica.

4 , in all cases quantitative recoveries were obtained indicating a good agreement between the known and determined vanadium amounts. The sorption of the spiked samples was, in most cases, in the range of 85 to $102 \%$ which demonstrated the suitability of the proposed methodology for the removal of vanadium species in water samples.

Table 3-Summary of model coefficients.

\begin{tabular}{llcc}
\hline Adsorption model & Parameter & $\mathbf{V}(\mathbf{I V})$ & $\mathbf{V}(\mathbf{V})$ \\
\hline Langmuir & $R^{2}$ & 0.9317 & 0.9876 \\
& $Q_{\max }(\mathrm{mg} / \mathrm{g})$ & 19.4 & 72.4 \\
Freundlich & $b(\mathrm{~L} / \mathrm{mmol})$ & 0.17 & 0.041 \\
& $R^{2}$ & 0.8395 & 0.9737 \\
& $\mathrm{~K}_{\mathrm{F}}(\mathrm{mg} / \mathrm{g})$ & 0.32 & 1.55 \\
Dubinin-Radushkevich & $1 / \mathrm{n}$ & 0.093 & 0.3723 \\
& $R^{2}$ & 0.794 & 0.9871 \\
& $B\left(\mathrm{~mol}^{2} / \mathrm{kJ}^{2}\right)$ & $8 \times 10^{-10}$ & $3 \times 10^{-9}$ \\
& $q_{\mathrm{s}}$ & 0.0004 & 0.0042 \\
& $E(\mathrm{~kJ} / \mathrm{mol})$ & 25 & 13 \\
\hline
\end{tabular}

Table 4-Real sample analysis for the sorption of $\mathrm{V}(\mathrm{IV})$ and $\mathrm{V}(\mathrm{V})$ by trypsin-immobilized silica (pH 4, $10 \mathrm{mg}$ sorbent, sorption time of $30 \mathrm{~min}$ ).

\begin{tabular}{lccr}
\hline & \multicolumn{2}{c}{ Vanadium Spiked $(\boldsymbol{\mu g} / \mathbf{L})$} & \\
\cline { 2 - 3 } & $\mathbf{V}(\mathbf{I V})$ & $\mathbf{V}(\mathbf{V})$ & \\
\hline Ultrapure Water & 20 & - & \\
& - & 20 & $93.9( \pm 3.1)$ \\
Tap Water & 10 & 10 & $85.0( \pm 3.0)$ \\
& 20 & - & $97.0( \pm 0.2)$ \\
Drinking Water-1 & - & 20 & $102.0( \pm 1.8)$ \\
& 10 & 10 & $87.6( \pm 1.9)$ \\
Drinking Water-2 & - & - & $96.0( \pm 4.5)$ \\
& 10 & 20 & $93.0( \pm 0.3)$ \\
& 20 & 10 & $89.0( \pm 1.2)$ \\
& - & - & $89.4( \pm 3.1)$ \\
& 10 & 20 & $92.0( \pm 0.5)$ \\
& & 10 & $91.0( \pm 1.4)$
\end{tabular}




\section{Conclusions}

Trypsin-immobilized silica was successfully synthesized and used for the removal of $\mathrm{V}(\mathrm{IV})$ and $(\mathrm{V})$ ions from aqueous solutions. Sorption parameters such as $\mathrm{pH}$, sorbent amount, solution volume, contact time, and initial concentration were optimized. It was observed that the sorption percentage towards $\mathrm{V}(\mathrm{IV})$ and $\mathrm{V}(\mathrm{V})$ was almost constant $(>90 \%)$ within the $\mathrm{pH}$ range 4 to 8 which demonstrated the possibility of using this sorbent for the sorption of both vanadium species. The negative $\Delta \mathrm{G}^{\circ}$ values showed that the adsorption of vanadium species onto trypsin-immobilized silica was feasible and spontaneous. The negative $\Delta \mathrm{H}^{\circ}$ value illustrated the exothermic nature of the adsorption. The negative $\Delta S^{\circ}$ values revealed that the orderliness of the adsorbed system was higher than the solution phase before adsorption. Both $\mathrm{V}(\mathrm{IV})$ and $\mathrm{V}(\mathrm{V})$ adsorption followed the Langmuir isotherm model. The proposed method was successfully applied to real samples for the removal of $\mathrm{V}(\mathrm{IV})$ and $\mathrm{V}(\mathrm{V})$ with sufficient accuracy and precision. On this basis, it can be concluded that trypsin-immobilized silica could be used to remove vanadium species in water, resulting in a solution to reduce environmental contamination.

\section{Acknowledgments}

The authors would like to thank the Center of Material Research for the facilities' SEM, TGA, BET, and the Environmental Research Center for ICP-MS measurements, at the Izmir Institute of Technology. Aslı Erdem Yayayürük would like to thank Arzu Erdem Şimşek and Onur Yayayürük for their valuable contributions to this study.

Submitted for publication November 28, 2016; accepted for publication May 24, 2018.

\section{References}

Abbas, A.; Conway, B. E. (2002) Investigation of Removal of $\mathrm{Cr}(\mathrm{VI}), \mathrm{Mo}(\mathrm{VI})$, $\mathrm{W}(\mathrm{VI}), \mathrm{V}(\mathrm{IV})$ and $\mathrm{V}(\mathrm{V})$ Oxyions from Industrial Wastewaters by Adsorption and Electrosorption at High-Area Carbon Cloth. J. Colloid Interface Sci., 251, 248-255.

Anirudhan, T. S.; Radhakrishnan, P. G. (2010) Adsorptive Performance of an Amine Functionalized Poly(hydroxyethylmethacrylate)-Grafted Tamarind Fruit Shell for Vanadium(V) Removal from Aqueous Solutions. Chem. Eng. J., $165,142-150$.

Atkins, P. (2006) Atkins' Physical Chemistry; Oxford University Press: New York, U.S.A.

Babu, B. V.; Gupta, S. (2008) Adsorption of Cr(VI) using Activated Neem Leaves: Kinetic Studies. Adsorption, 14, 85-92.

Bhatnagar, A.; Minocha, A. K.; Pudasainee, D.; Chung, H. -K.; Kim, S. -H.; Kim, H. -S.; et al. (2008) Vanadium Removal from Water by Waste Metal Sludge and Cement Immobilization. Chem. Eng. J., 144 (2), 197-204.

Bradford, M. M. (1976) A Rapid and Sensitive Method for the Quantitation of Microgram Quantities of Protein Utilizing the Principle of Protein-Dye Binding. Anal. Biochem., 72 (1-2), 248-254.

Chen, Z. L.; Owens, G. (2008) Trends in Speciation Analysis of Vanadium in Environmental Samples and Biological Fluids-A Review. Anal. Chim. Acta, $607(1), 1-14$.

Filik, H.; Berker, K. I.; Balkis, N.; Apak, R. (2004) Simultaneous Preconcentration of Vanadium(V/IV) Species with Palmitoyl Quinolin-8-Ol Bonded to Amberlite XAD 2 and their Separate Spectrophotometric Determination with 4-(2-Pyridylazo)-Resorcinol using CDTA as Masking Agent. Anal. Chim. Acta, 518, 173-179.
Gueu, S.; Yao, B.; Adouby, K.; Ado, G. (2007) Kinetics and Thermodynamics Study of Lead Adsorption on to Activated Carbons from Coconut and Seed Hull of The Palm Tree. Int. J. Environ. Sci. Technol., 4 (1), 11-17.

Guzman, J.; Saucedo, I.; Navarro, R.; Revilla, J.; Guibal, E. (2002) Vanadium Interactions with Chitosan: Influence of Polymer Protonation and Metal Speciation. Langmuir, 18, 1567-1573.

Hall, K. R.; Eagleton, L. C.; Acrivos, A.; Vermeulen, T. (1966) Pore- and SolidDiffusion Kinetics in Fixed-Bed Adsorption under Constant-Pattern Conditions. Ind. Eng. Chem. Fundam., 5 (2), 212-223.

Imtiaz, M.; Muhammad, M. S.; Xiong, S.; Li, H.; Ashraf, M.; Shahzad, S. M.; Shahzad, M.; Rizwan, M.; Tu, S. (2015) Vanadium, Recent Advancements and Research Prospects: A Review. Environ. Int., 80, 79-88.

Jansson-Charrier, M.; Guibal, E.; Roussy, J.; Le Cloirec, P. (1996) Vanadium (IV) Sorption by Chitosan: Kinetics and Equilibrium. Water Res., 30 (2), 465475.

Kavitha, D.; Namasivayam, C. (2007) Recycling Coir Pith, an Agricultural Solid Waste, for the Removal of Procion Orange from Wastewater. Dyes Pigments, 74 (1), 237-248.

Lazaridis, N. K.; Jekel, M.; Zouboulis, A. I. (2003) Removal of $\mathrm{Cr}(\mathrm{VI})$, Mo(VI), and $\mathrm{V}(\mathrm{V})$ Ions from Single Metal Aqueous Solutions by Sorption or Nanofiltration. Sep. Sci. Technol., 38 (10), 2201-2219.

Leiviskä, T.; Keränen, A.; Vainionpää, N.; Al Amir, J.; Hormi, O.; Tanskanen, J. (2015) Vanadium(V) Removal from Aqueous Solution and Real Wastewater using Quaternized Pine Sawdust. Water Sci. Technol., 72 (3), 437442.

Leiviskä, T.; Khalid, M. K.; Sarpola, A.; Tanskanen, J. (2017) Removal of Vanadium from Industrial Wastewater using Iron Sorbents in Batch and Continuous Flow Pilot Systems. J. Environ. Manage., 190, 231-242.

Li, H -Y.; Li, C.; Zhang, M.; Wang, K.; Xie, B. (2016). Removal of V(V) from Aqueous $\mathrm{Cr}(\mathrm{VI})$-Bearing Solution using Anion Exchange Resin: Equilibrium and Kinetics in Batch Studies. Hydrometallurgy, 165, 381-389.

Limousin, G.; Gaudet, J.; Charlet, L.; Szenknect, S.; Barthès, V.; Krimissa, M. (2007) Sorption Isotherms: A Review on Physical Bases, Modeling and Measurement. Appl. Geochem., 22 (2), 249-275.

Moskalyk, R. R.; Alfantazi, A. M. (2003) Processing of Vanadium: A Review. Miner. Eng., 16 (9), 793-805.

Mthombeni, N. H.; Mbakop, S.; Onyango, M. S. (2015) Magnetic Zeolite-Polymer Composite as an Adsorbent for the Remediation of Wastewaters Containing Vanadium. Int. J. Environ. Sci. Dev., 6 (8), 602-605.

Naeem, A.; Westerhoff, P.; Mustafa, S. (2007) Vanadium Removal by Metal (Hydr)Oxide Adsorbents. Water Res., 41, 1596-1602.

Nukatsuka, I.; Shımızu, Y.; Ohzek, K. (2002) Determination of V(IV) And V(V) by Electrothermal Atomic Absorption Spectrometry Following Selective SolidPhase Extraction and the Study on the Change in the Oxidation State of Vanadium Species in Seawater During the Sample Storage. Anal. Sci., 18 (9), 1009-1014.

Okamura, K.; Sugiyama, M.; Obata, H.; Maruo, M.; Nakayama, E.; Karatani, H. (2001) Automated Determination of Vanadium(IV) and (V) in Natural Waters Based on Chelating Resin Separation and Catalytic Detection with Bindschedler's Green Leuco Base. Anal. Chim. Acta, 443 (1), 143-151.

Padilla-Rodríguez, A.; Hernández-Viezcas, J. A.; Peralta-Videa, J. R.; GardeaTorresdey, J. L.; et al. (2015) Synthesis of Protonated Chitosan Flakes for the Removal of Vanadium(III, IV And V) Oxyanions from Aqueous Solutions. Microchem. J., 118, 1-11.

Parijaee, M.; Noaparast, M.; Saberyan, K.; Shafaie-Tonkaboni, S. Z. (2014) Adsorption of Vanadium(V) from Acidic Solutions by using Octylamine Functionalized Magnetite Nanoparticles as a Novel Adsorbent. Korean J. Chem. Eng., 31, 2237-2244.

Patel, B.; Henderson, G. E.; Haswell, S. J.; Grzeskowiak, R. (1990) Speciation of Vanadium Present in a Model Yeast System. Analyst, 115 (8), 1063.

Pyrzynska, K.; Wierzbicki, T. (2004) Determination of Vanadium Species in Environmental Samples. Talanta, 64 (4), 823-829.

Qi, L.; Xu, Z. (2004) Lead Sorption from Aqueous Solutions on Chitosan Nanoparticles. Colloids Surf. A, 251 (1-3), 183-190.

Roccaro, P.; Vagliasindi, F. G. A. (2015) Coprecipitation of Vanadium with Iron(III) in Drinking Water: A Pilot-Scale Study. (2015) Desalin. Water Treat., 55 (3), 799-809. 
Salis, A.; Meloni, S.; Ligas, M.; Casula, F.; Monduzzi, M.; Solinas, V.; Dumitriu, E. (2005) Physical and Chemical Adsorption of Mucor Javanicus Lipase on SBA-15 Mesoporous Silica. Synthesis, Structural Characterization, and Activity Performance. Langmuir, 21 (12), 5511-5516.

Sirviö, J. A.; Hasa, T.; Leiviska, T.; Liimatainen, H.; Hormi, O. (2016) Bisphosphonate Nanocellulose in the Removal of Vanadium(V) from Water. Cellulose, 23, 689-697.

Stuart, B. (2004) Infrared Spectroscopy: Fundamentals and Applications; Wiley: Chichester, U.K.

Takei, T.; Mukasa, K.; Kofuji, M.; Fuji, M.; Watanabe, T.; Chikazawa, M.; et al. (2000) Changes in Density and Surface Tension of Water in Silica Pores. Colloid Polym. Sci., 278 (5), 475-480.

Taqvi, S. I. H.; Hasany, S. M.; Bhanger, M. I. (2007) Sorption Profile of Cd(II) Ions onto Beach Sand from Aqueous Solutions. J. Hazard. Mater., 141 (1), 3744.

Umpleby, R. J.; Baxter, S. C.; Bode, M.; Berch, J. K.; Shah, R. N.; et al. (2001) Application of the Freundlich Adsorption Isotherm in the Characterization of Molecularly Imprinted Polymers. Anal. Chim. Acta, 435 (1), 35-42.

U.S. Environmental Protection Agency (2009) Drinking Water Contaminant Candidate List, CCL3; Washington, D.C.

Vega, E. D.; Pedregosa, J. C.; Narda, G. E.; Morando, P. J. (2003) Removal of Oxovanadium(IV) from Aqueous Solutions by using Commercial Crystalline Calcium Hydroxyapatite. Water Res., 37, 1776-1782.

Worthington, A. (1972) Enzymes, Enzyme Reagents, Related Biochemical. Worthington Biochemical Corporation: New Jersey, U.S.A.

Xiong, C.; Qin, Y.; Hu, B. (2010) On-Line Separation/Preconcentration of V(IV)/ $\mathrm{V}(\mathrm{V})$ in Environmental Water Samples with CTAB-Modified Alkyl Silica Microcolumn and their Determination by Inductively Coupled PlasmaOptical Emission Spectrometry. J. Hazard. Mater., 178 (1-3), 164-170.

Yayayürük, A.; Yayayürük, O. (2017) Adsorptive Performance of Nanosized ZeroValent Iron for V(V) Removal from Aqueous Solutions. J. Chem. Technol. Biotechnol., 92, 1891-1898.

Yurdakoç, M.; Seki, Y.; Karahan, S.; Yurdakoç, K. (2005) Kinetic and Thermodynamic Studies of Boron Removal by Siral 5, Siral 40, and Siral 80. J. Colloid Interface Sci., 286 (2), 440-446.

Zhang, B.; Hao, L.; Caixing, T. C.; Songhu, Y. S.; Chuanping, F. C.; Jinren, N. J.; Borthwick, A. G. L. (2015) Microbial Reduction and Precipitation of Vanadium(V) in Groundwater Immobilized Mixed Anaerobic Culture. Bioresour. Technol., 192, 410-417. 